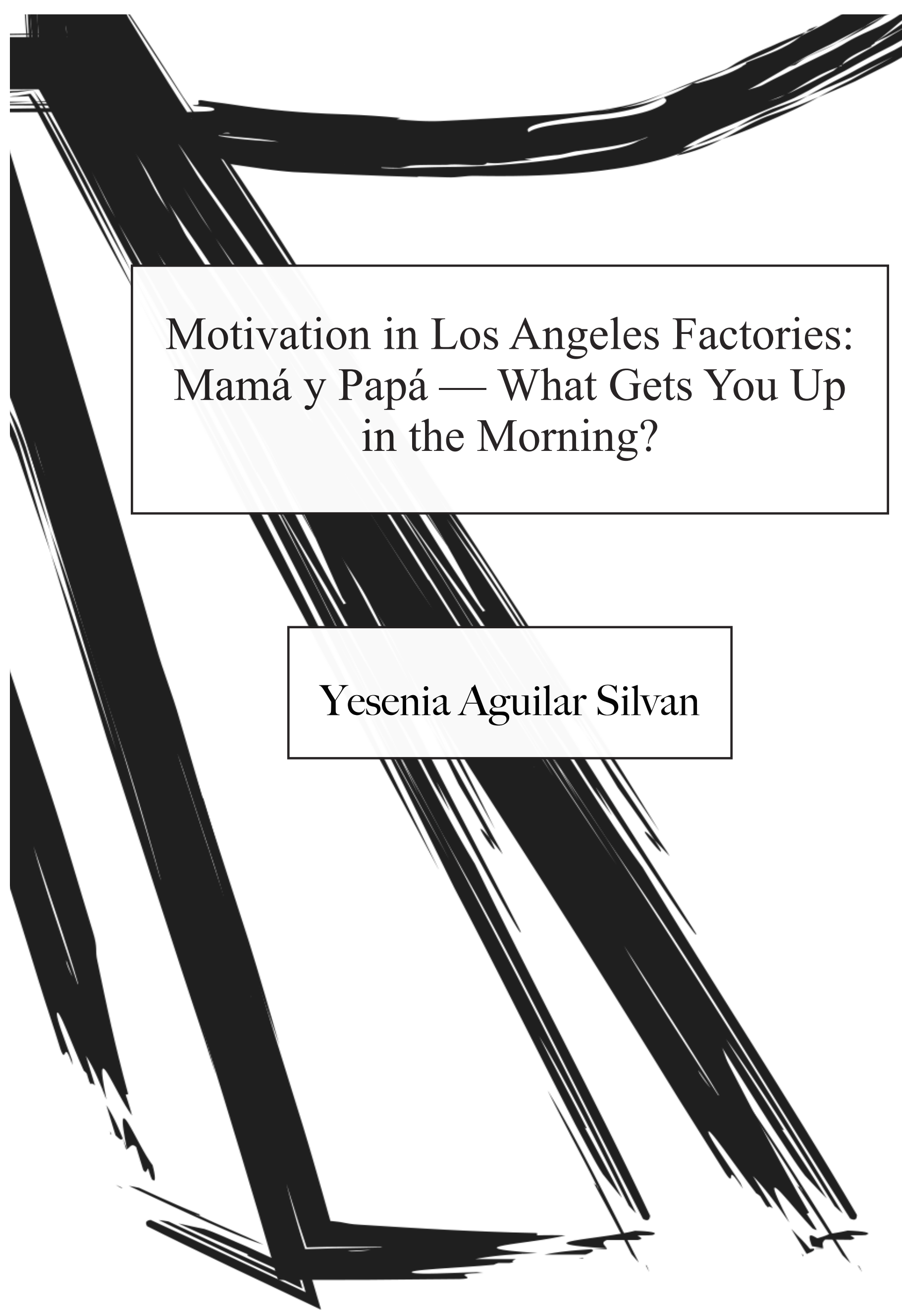





\title{
Motivation in Los Angeles Factories: Mamá y Papá — What Gets You Up in the Morning?
}

Yesenia Aguilar Silvan

\begin{abstract}
Undocumented Latino workers often work in unsafe and underpaid jobs. There is limited research on this demographic, especially as it relates to the factors that motivate these workers to work under undesirable working conditions. Self-Determination Theory states that relatedness, competence, and autonomy are three intrinsic psychological needs that, when met, will lead to optimal human flourishing. These three needs directly translate to the workplace. A workplace that provides an environment for workers to have a sense of belonging, accomplishment, and self-control, unlocks greater satisfaction, performance, and wellbeing. Moreover, SelfDetermination Theory states that intrinsic psychological needs can be challenged by extrinsic rewards and punishments. This raises a question: what motivates undocumented Latino workers to continue working in undesirable working conditions? This study qualitatively examines the potential factors affecting undocumented Latino factory workers' motivation in the workplace, and this study provides a platform for these workers to share their daily life struggles.
\end{abstract}

Keywords: Undocumented, Factory Workers, Latinos, Motivation, Los Angeles, Self-Determination Theory 
On August 2, 1995, labor officials raided a sevenfloored apartment complex, surrounded by a barbed wire fence and a six foot metal-spiked brick wall; it was an illegal garment manufacturing shop in El Monte. When the officials raided the shop, they found 72 workers working 17 hours a day, 7 days a week, for an hourly payment of $\$ 1.60$. (Noble, 1995). Although this scenario might be an extreme case, garment workers still continue to work in undesirable conditions (i.e., unsafe settings with long irregular hours and where wage-theft often occurs). These "not so extreme" yet undesirable conditions are part of the "new sweatshops" in the United States. These "new sweatshops" refer to half of the entire apparel workforce that work below the legal minimum wage and/or without legal pay for overtime hours (Ross, 2002). The U.S. Department of Labor investigated 77 Los Angeles garment factories sewing clothes for Forever 21, Ross Dress for Less, and TJ Maxx. From April through July of 2016, they found that workers in these 77 factories were paid as little as $\$ 4$ and an average of $\$ 7$ an hour for 10-hour days spent sewing clothes. One worker in West Covina made as little as $\$ 3.42$ per hour during three weeks of sewing TJ Maxx clothing. Most of these underpaid workers in garment factories are undocumented Latinos (Gordon, 2017).

Undocumented Latino workers have "jobs that are risky not only because of the potential for physical injury but also because being without basic human rights and protections almost guarantees undocumented Latino workers exploration by employers" (Fernández-Esquer, Agoff, \& Leal, 2017). Fernández-Esquer et al. (2017) states that such exploitations include workplace injury and hazards, and wage theft. For the past 40 years, undocumented Latino workers have experienced a large wage-theft. For example, undocumented Mexicans earned approximately 12 percent less than legal immigrants for doing equal labor. Undocumented non-mexicans (e.g., Guatemalans, Chileans, and Peruvians,) earned approximately 7 percent less compared to legal immigrants who were engaged in the same jobs (Massey, Durand, and Pren, 2016). Undocumented Latino workers endured exploitative working conditions and refrained from seeking health care when they have gotten sick or injured at 
work because of the fear of losing their jobs or of being deported (Fernández-Esquer et al., 2017). Undocumented Latinos work in unsafe settings with long irregular hours and where wagetheft often occurs, yet, research has not examined the motivating factors that help these workers' endure working in these settings.

In order to start tackling this question, Self-Determination Theory needs to be examined. Self-Determination Theory states that human motivation is intrinsic and based on having the psychological needs of competence, relatedness, and autonomy met (Deci and Ryan, 2011). Competence refers to an individual's feeling of having the right skill set to complete a task. Relatedness refers to an individual's feeling or experience of belongingness or love. Autonomy refers to an individual's need to experience independence and individualism (Deci and Ryan, 2011). Deci and Ryan (2011) explained that an individual is willing to give up these intrinsic psychological needs if there are extrinsic rewards or punishments in place (e.g., receiving a raise, being awarded employee of the month, or being fired or laid off).

Ilardi, Leone, Kasser, and Ryan (1993) tested SelfDetermination Theory and found that this theory could be applied in real life. They found that Self-Determination Theory was directly applicable to the workplace, and that factory workers who experienced autonomy, competence, and relatedness had more job satisfaction compared to those who did not have these needs met. Gagne and Deci (2005) challenged this study by arguing that people felt more job satisfaction because they had extrinsic motivation, meaning they were motivated by external rewards such as money or bonuses.

In order to objectively address the factors that motivate undocumented Latino factory workers to work in undesirable conditions, researchers need to survey this population's intrinsic and extrinsic motivation with validated measures. However, research in this field is limited. There are no qualitative nor quantitative studies that have examined workplace motivation in undocumented Latino factory workers and to date, there are no validated measures to assess motivation in the workplace for the Latino population. Therefore this study aims to explore the factors that affect undocumented Latino factory workers' motivation and 
give voice to an under-studied population.

\section{Methods}

\section{Participants}

This study looked at the daily lives of two undocumented garment factory workers from the city of El Monte. They were one male and one female, $(M=45$ years $)$. These participants were recruited through a convenience sample as it was not possible to randomly sample such marginalized population. These participants were required to be of Latino descent and have citizen and/or non-citizen children living in the United States in order to complete the interview.

\section{Data Collection}

Data were primarily collected through 45-minute individual interviews. An effective strategy to examine exploratory studies is to collect qualitative data (Krueger \& Casey, 2014). The interviewer was a bilingual (Spanish and English) undergraduate student with experience working with undocumented Latino populations. All interviews with the undocumented Latino factory workers were conducted in Spanish, and then translated into English. These interviews took place in the participants' homes to reduce their burden of transportation. All participants provided verbal consent to have the interview audio recorded for research purposes, and they decided to participate in the study to increase the awareness of the daily lives of factory workers.

\section{Data Analysis}

The interviews were analyzed by following directed content analysis (Hsieh \& Shannon, 2005). Directed content analysis is grounded in a deductive top-bottom approach which consists of having a priori themes followed by conducting refinements to the codebook. This analysis methodology is useful when addressing exploratory research that is based on a theoretical background. In the case of this paper, although studies on undocumented Latino factory workers are very limited, the general theoretical study of human motivation has been highly 
studied. The a priori themes in the codebook were based on Self-Determination Theory; themes related to Competence, Relatedness, Autonomy, and Extrinsic Rewards were expected to be found in the interviews. Refinements to this codebook were made during a process of iterative coding and recoding of data. After coding all the data once, an unexpected theme of work routine was found, and then added to the codebook. The final codebook contained the themes 1) Work Routine, 2) Competence, 3) Relatedness, 4) Autonomy, and 5) Extrinsic Rewards. The final codebook was used to recode all data, and consensus was reached among 2 researchers regarding code application (i.e., researchers agreed on which quotes were related to the corresponding themes).

\section{Preliminary Qualitative Findings}

The overarching theme framing participants' experience as an undocumented Latino factory worker in Los Angeles was the "razon por cual trabajamos" ["reason for why we work"]. From the narratives, a daily account of 1) Work Routine and activities set the background for the themes displaying the main constructs of Self Determination Theory: 2) Competence, 3) Relatedness, 4) Autonomy, and 5) Extrinsic Rewards. These interrelated themes provide a testimony of the motivation of these undocumented Latino factory workers as they work in undesirable conditions.

\section{Work Routine}

When these undocumented factory workers were asked to talk about an ordinary day, they both begun with the mentioning their work. They did not mention having breakfast with their family, helping their children prepare for school, or taking their children to school. These undocumented factory workers, like those interviewed by Orellana et. al (1998), worked over 8 hours a day and only saw their children after their work responsibilities were completed. To fully understand the lives of these individuals and what motivates them, it is important to get a comprehensive overview of what their duties as garment workers were.

Hipolita began retelling a typical day with her "jornada de trabajo" ["work shift"] from 3 p.m. to 11 p.m. At 3 p.m. she began 
separating clothes by sizes, putting them in printing machines, taking them out and placing them in industrial ovens to dry, packing them to be shipped, and fixing errors in the garments that were caused by the cheap material. This was all done while having to clean the restrooms and running errands for the managers and the people in the office.

Beto worked from 7 a.m. to 3 p.m. for his first job and he worked his second factory job from 3:30 p.m. to 11 p.m. At the factory, Beto manufactured cloth and added designs as instructed. This was done through industrial machinery controlled by a computer. Beto's main duty was to control the computer and fix the needles that would break.

The two interviews covered various day-to-day tasks that were expected to be completed at work. Hipolita had to do very detailed work such as fixing machine-caused errors and domestic related work such as cleaning bathrooms. Beto had to use larger machinery and have basic computer skills. Despite the differences between the day-to-day tasks that were covered, both of the participants introduced similar factors that motivated them to continue working in the factory.

\section{Competence}

Hipolita explains that when it came to completing certain tasks at work, often she felt she was unable to complete the task. She explained:

Era como alrededor de 2 mil piezas que teníamos que sacar durante el transcurso de las 8 horas de trabajo. Muchas veces nos descansaban por no alcanzar el blanco que ellos ponían. Aunqué muchas veces nos ayudaban los managers, muy rara las veces que alcanzábamos esas piezas porque ellos las querían sin error.

[It was like around 2,000 pieces that we had to complete during the course of the 8 hours. Many times we were laid off for not reaching the target that they put. Although many times the managers helped us, it was very rare the times we reached 
those numbers because they wanted them without error.]

This raises a considerable concern because even with the managers' help, the workers were not able to hit the target goal of 2,000 pieces per person. According to Hipolita, it was "cruel" that the managers, knowing that this target was nearly impossible to reach, would lay off workers that could not hit the target. Importantly, Hipolita did not say the work was physically tiring or difficult; her concern was related to the possibility of being out of a job at any moment for not reaching the target goal.

Hipolita explained that most of the workers in this factory were women and that the managers decided who was laid off, fired, and received more work hours. She stated that the female workers' fear of being laid off led the managers to more easily engage in sexual abuse against the wokers. Hipolita explained:

Como por ejemplo si querían algo más, por decir una invitación o algo indebido y si tu no aceptabas, muchas veces ellos te agarraban y te descansaban por no ceder a lo que ellos querían. Pero a las otras personas que si accedían, les daban más tiempo. Tenían más preferencia. [Like for example if they wanted something, per se a [sexual] invitation or something improper and if you did not accept, many times they grabbed you and laid you off for not giving them what they wanted. But the other people that would agree, they were given more hours of work. They had more preference.]

Hipolita later explained that by "algo mas" ["something else"], she was referring to the sexual requests to have intercourse by the managers. For those who did not consent they would be told by the managers, "Sabes que nada más va a trabajar 3 horas y se va para su casa" ["You know what, you will only work 3 hours and go home"] or they would arrive to their scheduled hours to find that there was another female worker working their shift without 
any notice. Hipolita states, "Muchas veces nos regresamos pues del trabajo porque ya otras estaban haciendo el trabajo" ["Many times we would come back from work because well the others were already doing the work"]. These workers not only had to deal with the constant instability of not knowing whether they would be laid off for not completing the target of 2,000 pieces of clothing, but they also had to deal with the fact that regardless of how good they were at their jobs, their dissent against the manager's sexual requests could get them laid off as well.

Nonetheless, when I asked Hipolita where she saw herself in a couple of years, she stated: "Pues yo me siento bien o sea me siento fuerte, me siento como que voy a poder seguir trabajando. Aunque siga en el mismo estatus sin papeles, siento que voy a poder seguir trabajando hasta por mucho tiempo más." [Well I feel good I mean I feel strong, I feel like I will be able to continue working. Even though I'll continue in the same status without documentation, I feel like I will be able to continue working until a long time.] Regardless of how incompetent Hipolita felt at work regarding reaching the factory's 2,000 piece goal and the manager's sexual requests, she was confident in her own ability to continue being a good worker and staying physically strong to handle any type of labor.

\section{Relatedness}

From Beto's description about the work environment of the factory, the managers provided an approachable and sociable work environment because the managers were a family who emigrated from Mexico. Beto explained his relationship with the managers:

Nos identificamos y nos llevábamos muy bien. Luego yo les llevaba algo y se los llevaba o luego ellos la compraban. Era una relación de trabajo pero también muy amistoso, como que nos entendíamos y la forma que nos llevábamos era bien.

[We identified and we got along very well. Then I would bring them something and take it to 
them or other times they would buy it. It was a work relationship but also very friendly, as we understood each other and the way we got along was good.]

This relatedness was evident in the way Beto spoke about the factory. For example, he explained that he called one manager by his nickname "el mudo" ["the mute"] and another one by his first name to show "respeto" [ "respect"] because he had received a university degree. Beto explained that the managers and the workers ranged in education levels, but they held the same undocumented status. Their undocumented status seemed to offer a clear connection between the managers and the workers, and although there was a hierarchy within the factory, the workers seemed to feel they were friends with the managers. In addition, most of the workers were friends with the managers prior to becoming their employees. They were also part of various community soccer teams during the weekends. It was evident from Beto's description, that he felt a sense of belongingness and felt cared for at work. This seemed to help Beto with the physical exhaustion that he would experience during his second work shift.

\section{Autonomy}

Beto stated that the factory where he worked, and the neighboring factory that partnered with them, had a relaxed and flexible setting; workers were allowed to keep a radio and walk over to another station to chat. He stated that people were allowed to go on breaks when they wanted, they were able to stop and chat with others in different stations, and they were able to go to the vending machines to buy snacks when they wished. In the workplace, Beto felt he was independent enough to take decisions regarding when to take a break and when to talk to his coworkers without feeling he would get punished for this. In addition to this, Beto had the flexibility of choosing when to clock in for this shift. He stated:

Pues ahí era, yo doy gracias a Dios que tenía la opción de acomodar mí tiempo. Yo por ejemplo, 
entraba a las 7 a trabajar en el taller y de ahí completaba mis 8 horas y tenía el horario abierto para llegar ahí en la fábrica. Podía empezar a las 3:30 P.M., las 4:00 P.M., o 5:00 P.M. Y esa era la opción que yo tenía y gracias a dios que tenía esa oportunidad que los managers me dieron. [It was, I thank God that I had the option of accommodating my time. For example, I would go to work at the shop at 7 and that's where I completed my 8 hours and had a flexible schedule to get to the factory. I could start at 3:30 P.M., 4:00 P.M., or 5:00 P.M. And that was the option I had and thank God I had that opportunity that the managers gave me.]

This flexibility made Beto feel autonomous as he was able to take decisions at work on his own. The autonomy he felt helped make the day-to-day work tasks bearable.

Extrinsic Rewards

When these factory workers retold their day-to-day work tasks in detail, Hipolita facing sexual harassment and Beto facing physical tiredness and animosity from his coworkers, they showed high awareness of the difficulty of their lives. Nevertheless, like Orellana et. al (1998) stated, "they did not emphasize their own hardships; their attention focused on their children, and especially on their children's futures." Although, the parents did show high attention focused on their children's futures like Orellana et. al (1998) stated, they also showed high attention focused on what they were providing to the children as parents. That is, they also focused on what they saw good parenting as and what made them feel good as parents.

When I asked Hipolita what she did in order to make the hours pass at her job, she stated:

El como el motivo de uno, de madre, es de tener a sus hijos y darle lo mejor. Es lo que te motiva a echarle ganas, a ser puntual a tu trabajo, estás 
pensando en hacer lo mejor o sea a estar atenta a tu trabajo a lo que estás haciendo.

[The motivation of one, of a mother, is to have your children and give them the best. It is what motivates you to make an effort, to be punctual in your job, you are thinking in doing the best or to be attentive to the work you are doing.]

Likewise, when I asked Beto the same question. He stated:

Ya venía cansado del taller y pues sentía el peso del trabajo. Ya cuando llegaba a la fábrica pues eso también era trabajo físico. Pero era menos cansado por las metas que yo me ponía. Eso era lo que me motivaba, ver a mi familia. [I already came tired from the shop and well I felt the weight of the work. When I arrived at the factory well that was also physical labor. But it was less tiring for the goals I would make for myself. That was what motivated me, seeing my family.]

Beto spoke more generally about the way in which seeing his family at the end of the day was one of his motivating factors. He did not specify his children like Hipolita, but he made a reference to the whole family unit as a motivating factor.

Hipolita stated that her children were her motivation. Not only that, but she stated that as a "madre" ["mother"], she had to respond to the presence of children. For example, she had to respond to her children by putting effort, being punctual, thinking about doing the best, and being attentive to the work. What is interesting is that Hipolita's children affected her physically and mentally during her job; her children motivated her to be a good worker by being punctual and thinking about doing her best. She gave various criteria of what makes a good worker, and how she fulfilled that criteria. It seemed that that by being a good worker, she thus was a good mother. This would explain the pressure that was felt to avoid mistakes, being tardy, and conflicts with 
coworkers. If she did not avoid these things, then that led to less worked hours; less worked hours meant less opportunities she could give her children. In essence, the more opportunities she gave her children, the better a mother she was.

Hipolita explains that the opportunities she provides for her children were first to "pagar la renta" [ "pay the rent"], "tener para la comida" ["have means for food"], "proveer vestimenta" ["provide clothing"], and "servicios del apartamento" ["bills for the apartment"]. Then, her ultimate goal was to be able to say yes to her children's request for treats, snacks, little toys, or going to the park. The prices regarding the children's requests were not high, however, the ability to give them the option per se to either buy an ice cream or a toy was vital for Hipolita.

Beto further explains this sense of opportunities. Like Hipolita, he too aspired to give his children the option to want something and have the hope of receiving it. According to what Beto and Hipolita states, providing was relative to their pasts, not relative to how much their neighbors or coworkers were providing for their children. For example, Beto states:

Yo quería darles mejor vida que tuve porque yo padecí de muchas cosas de niño y si sentía esa tristeza de querer algo y no poder tenerlo y entonces yo decía que cuando yo me case y tenga a mi esposa y a mis hijos yo decía eso que yo me iba a esforzar para que mis hijos no tuvieran que desear algo y yo no poderle dáselo.

[I wanted to give them a better life because I perished many things as a child and I felt that sadness of wanting something and not be able to have it and so I decided that when I got married and had my wife and my children I decided that I would make an effort so that my children would not have to desire something and not be able to give it to them.]

For Beto, like I had mentioned before, providing meant giving his children more opportunities than what he had received 
in the past. He explains that his childhood was very different from his children's childhood. In addition, he states that his children's childhood was getting better compared to a few years back. When looking back at his children's childhood, he states:

Yo me acuerdo que antes yo los llevaba al McDonald's porque ahí pues estaban las cosas baratitas y comprábamos esos porque solamente tenía un trabajo y se tenía que estirar los gastos. Pero ya después que agarre otro trabajo y ya gracias a dios nos fuimos componiendo y brincamos ese McDonald's y íbamos a otros lugares a comer y si a ora les preguntaba adonde querían ir a comer. I remember that before I would take them to McDonald's because there the things were cheap and we'd buy that because I solely had one job and the expenses had to be stretched. But after I got the other job and thanks to God we got better and we surpassed that McDonald's and we'd go other places to eat and now I'd ask them where they wanted to go eat.]

Beto notes that his children had more opportunities than he did as a child. When he was working two jobs, he was able to provide even more opportunities to his children compared to when he had only one job. Beto and Hipolita needed to provide a sense of opportunities, even if the items or dinners were "baratos" ["cheap"]. For instance, Beto right away pointed out "obviamente no caros o de lujo verdad pero si íbamos a un restaurantito más o menos o hamburguesas" ["obviously not expensive or luxurious right but we would go to a restaurant of more or less [quality] or a hamburger place"]. In the participant's perspective, the sense of having "opciones" [ "options"] meant that they were fulfilling the task of providing for their family.

This concept of providing or having options plays an interesting role as it is a motivating factor for these workers, but because they face insecure jobs for reasons such as documentation, the demand to provide or make opportunities for 
the family also becomes a stressful factor. Providing itself does not cause a problem, like Beto had mentioned; to him "eso es lo que me motiva" ["that's what motivates me"]. However, not having the means to provide causes a stressful time as it results in having doubts as a parent and whether they are doing a good job or not.

In addition to focusing on what it meant to provide for family, undocumented Latino factory workers showed interest in their children's future. This finding adds complexity to Cartwright and Shingles (2011) argument that Latinos operate with a "present time orientation", meaning that Latinos are focused on the "right now" rather than on the past or on future events or outcomes. Although these undocumented Latino factory workers were focused on their daily work routines, they also focused on the future of their children. These interviews challenge the "present time orientation" because the participants showed importance regarding their children's future.

Hipolita expressed that she saw her children in the future as "algo superior" ("being superior") and "con un buen trabajo" ("with a good job"). However, her first response was that she saw herself in the future as physically strong and able to continue working at the pace that she was already working. This becomes particularly important when regarding the unsafe and unsanitary conditions from a factory setting. These undesirable conditions were not considered at all, thus, it shows to what extent she feels motivated. For instance, she seemed to take her health, the ability to become a good parent, and her children's futures as motivating factors in the workplace. When regarding the future, she did not seem to show dependence on the government, work conditions, nor her undocumented status.

Unlike Hipolita, Beto to some extent did mirror Cartwright and Shingles (2011) argument that Latinos operated in the "present time orientation". This, however, was only true when he thought about his own future but not for his children's future. When I asked him where he saw himself in the future, he stated:

Yo donde me veo? Pues yo no sé. No me he puesto a pensar en el futuro de cómo voy a estar, donde 
voy a quedar, adonde voy a caer. O sea, ahorita pienso en mis niños. Que sean gente de bien, que sea gente que aporten a la sociedad, y yo no sé, ahorita yo no me siento viejo para estar pensando en un asilo o en México que quiera regresar. Pero yo no sé, no me he puesto a pensar adónde voy a quedar, a donde voy a morir.

[Where I see myself? Well I don't know. I haven't given thought to the future in where I will be, where I will end up, where I will fall. I mean, right now I think about my kids. That they are people of good, that they are people that contribute to society, and I don't know, right now I don't feel old to be thinking in a retirement home or in wanting to go back to Mexico. But I don't know, I haven't given thought to where I will end up, to where I will die.]

When I asked this question, Beto seemed confused and conflicted. It seemed like at a certain point in his life, he stopped thinking about his own future. When he was discussing what it meant to provide for his children and how they had more opportunities than he had, he expressed that as a young man he saw himself in the future as a man who would give his children opportunities. Here, it was seen again, that children and providing opportunities were motivating factors for Beto while working in a undesirable conditions in a garment factory.

\section{Discussion}

When studying Self-Determination Theory in a factory setting, especially in garment factories from Los Angeles, there was evidence for and against the constructs of competence, relatedness, autonomy, and extrinsic rewards. Competence was shown as both absent in the factories and present in the lives of the workers. For example, managers had put very difficult goals for their workers and many workers ended up feeling incompetent, however, workers felt competent in their own 
skill to remain strong throughout such adversities. Relatedness was observed when factory workers mentioned their ability to relate to other colleagues and managers based on their ethnicity and undocumented status. Autonomy was noted when workers mentioned having the ability to walk over to stations to chat with their colleagues and taking their breaks when they wanted.

However, the typical extrinsic rewards like medical coverage, bonuses, and a high pay were not present in a garment factory. Like it was evident in the preliminary analyses of this project, there were other factors motivating undocumented Latino factory workers to continue working in such harsh conditions. These undocumented Latino factory workers focused primarily on their families. This focus on family brings nuance to the concept of extrinsic rewards. Providing for their family made them feel like good parents, and this then further motivated them to be good workers and apply that same work ethic into their jobs. Undocumented Latino factory workers were motivated to go into work because they felt like good parents, and they felt like they could provide. They were not motivated by getting higher income and more benefits as these typical extrinsic factors were almost non-existent in garment factories.

This extrinsic reward that arrived from the data could be explained by familism or the core cultural values guiding Latino families (Stein, Cuptito, Mendez, Prandoni, \& Huq, 2014). Familism has been evaluated and seen through three different components: obligation to provide material and emotional support, use relatives as behavioral and attitudinal referent, and the extent to which family members are reliable sources of support, however, there has been new aspects added like protecting the family name, family reciprocity and interconnectedness, and the subjugation of self for the family (Steidel \& Contreras, 2003). Compared to European and Asian cultural backgrounds, Latinos are typically higher in familism, and familism has been found to obtain greater benefits for psychological health from closeness to family and perceived support (Campos, Ullman, Aquilera, \& Dunkel, 2014). Campos et al. (2014) states that nurturing relationships (i.e. what occurs in familism) with parents and siblings lead to more secure socially competent individuals who grow to attain higher status 
and greater success.

These past studies and the in-depth thematic analyses of these two narratives, point out the importance of competence, relatedness, and autonomy in the workplace. In addition, the data yielded the importance of familism as a major contributing factor for motivation. In addition to the established constructs of competence, relatedness, and autonomy, familism may be a new aspect of extrinsic rewards that may further explain why undocumented Latino factory workers stay motivated to continue working under undesirable conditions.

\section{Future Research}

In order to objectively measure Latino's motivation in the workplace, future researchers should create culturally sensitive measures that incorporate questions about familism within the intrinsic factors subscale. For instance, the Academic Motivation Scale (AMS) can be changed to reflect a work setting (i.e. change the original statement "because I believe that being a good student is valuable" to "because I believe that being a good worker is valuable"). After changing the context of the scale, the questions could be changed to be more reflective of the familism that exist in the Latino population. For instance, the original item "because I want to show myself that I can be successful in my job" can be changed to "because I want to show my family that I can be successful in my job". By doing this, scales become more reflect of the Latino population, and researchers can then better objectively assess motivation in the workplace for the Latino population.

\section{Limitations}

This study was based on an understudied, difficult to reach population. Due to the difficulties of reaching the population, analyses only focused on two participants. Because analyses were focused on two participants, these results are not generalizable. Researchers should continue working with qualitative analyses since research with this population is in the exploratory stages, however, researchers should take extra measures to ensure a larger sample size. Having a bigger sample will allow researchers 
to get more perspectives within this population. It is not until this population is more studied, that researchers can create validated and cultural sensitive measures for measuring workplace motivation for undocumented Latino factory workers. This project is one of the first steps in undertaking this research gap with the hopes of one day bettering the daily lives of undocumented Latino factory workers. 


\section{References:}

Campos, B., Ullman, J. B., Aguilera, A., \& Dunkel Schetter, C. (2014). Familism and psychological health: The intervening role of closeness and social support. Cultural Diversity and Ethnic Minority Psychology, 20(2), 191-201.

Cartwright, L., \& Shingles, R. R. (2011). Cultural considerations when working with Mexicans. Human Kinetics. Retrieved from http:/www.humankinetics.com/excerpts/excerpts/ cultural-considerations-when-working-with-mexicans

Deci, E. L., \& Ryan, R. M. (2011). Self-determination theory. Handbook of Theories of Social Psychology, 1, 416-433.

Fernández-Esquer, M. E.,Agoff, M. C., \& Leal, I. M. (2017). Living Sin Papeles: Undocumented Latino Workers Negotiating Life in "Illegality". Hispanic Journal of Behavioral Sciences, 39(1), 3-18.

Gagné, M., \& Deci, E. L. (2005). Self-determination theory and work motivation. Journal of Organizational Behavior, 26(4), 331-362.

Gordon, E. A. (2017). 100 years of LA garment work. Guardian Sydney, (1771), 11.

Hsieh, H. F., \& Shannon, S. E. (2005). Three approaches to qualitative content analysis. Qualitative Health Research, 15(9), 1277-1288.

Ilardi, B. C., Leone, D., Kasser, T., \& Ryan, R. M. (1993). Employee and Supervisor Ratings of Motivation: Main Effects and Discrepancies Associated with Job Satisfaction and Adjustment in a Factory Setting. Journal of Applied Social Psychology, 23(21), 1789-1805.

Krueger, R. A., \& Casey, M. A. (2014). Focus groups: A practical 
guide for applied research. Mathura Road, New Delhi: Sage Publications.

Massey, D. S., Durand, J., \& Pren, K. A. (2016). The precarious position of Latino immigrants in the United States: A comparative analysis of ethnosurvey data." The ANNALS of the American Academy of Political and Social Science, 666(1), 91-109.

Noble, K.B. (1995). Los Angeles Sweatshops Are Thriving, Experts Say. Retrieved from https://www.nytimes.com/1995/08/05/ us/los-angeles-sweatshops-are-thriving-experts-say.html.

Orellana F. M., Monkman, K., MacGillivray L. (1998). Parents and Teachers talk about literacy and success. Retrieved from http://www.ciera.org/library/reports/inquiry-3/3-020/3-020p. pdf.

Ross, R. (2002). The new sweatshops in the United States: how new, how real, how many, and why. Free Trade and Uneven Development: The North American Apparel Industry after NAFTA, 100-122.

Steidel, A. G. L., \& Contreras, J. M. (2003). A new familism scale for use with Latino populations. Hispanic Journal of Behavioral Sciences, 25(3), 312-330.

Stein, G. L., Cupito, A. M., Mendez, J. L., Prandoni, J., Huq, N., \& Westerberg, D. (2014). Familism through a developmental lens. Journal of Latina/o Psychology, 2(4), 224-250. 
